\title{
CAPACITY FOR DEVELOPING TRAINING PROGRAM OF PEDAGOGICAL UNIVERSITIES OF VIETNAM
}

\author{
NGUYEN THITINH ${ }^{1}$, HA THI KIM LINH ${ }^{2}$ \& HUYNH TAN HOI ${ }^{3}$ \\ ${ }^{I}$ Professor, Pedagogical University, Thai Nguyen University, Thai Nguyen Province, Vietnam \\ ${ }^{2}$ Senior Lecturer, Pedagogical University, Thai Nguyen University, Thai Nguyen Province, Vietnam \\ ${ }^{3}$ language Lecturer FPT University, Ho Chi Minh City, Vietnam
}

\begin{abstract}
The capacity of developing lecturers 'training programs is the supplementary actions, updating, adjusting, perfecting and renewing lecturers' programs to help teachers training institutions effectively implement the training activities in relationship with stakeholders. Survey results of administrators and lecturers at 5 universities in Vietnam show that lecturers still have some limitations on the capacity of developing training programs including capacity of surveying stakeholders, additional capacity of module content to meet learning outcomes, capacity of program self-assessment, using program completion evaluation results, lecturers of pedagogical universities have high demands on fostering training program development capacity, etc. Principal and teachers at pedagogical universities in Vietnam need to pay attention to the above issues to organize fostering and self-fostering capacity to develop training programs for lecturers.

KEYWORDS: Capacity, Training Program Development \& Training Programs
\end{abstract}

Received: May 26, 2020; Accepted: Jun 16, 2020; Published: Jul 18, 2020; Paper Id.: IJMPERDJUN2020385

\section{INTRODUCTION}

Teachers of pedagogical universities have an extremely important role in developing teacher training programs that meet the requirements of renovating general education. Lecturers are the core force to develop the program, develop the program, organize the implementation of the program and evaluate and adjust the program to meet practical requirements. Lecturers are the conditions that determine the success and effectiveness of the training program. Especially for the subject curriculum, lecturers are the ones who decide on the update, development, object, practicality of the subject; lecturers must regularly update, supplement and renew the program every year to improve the training quality to meet the requirements of renovation of general education and renovation of preschool education [1].

\section{II.Content of Research}

\section{A. Some Basic Issues about the Capacity of Curriculum Development of Pedagogical University Lecturers}

Training programs are concepts that are approached in many different angles. According to the Vietnamese Dictionary of Education, the training program is understood as "Official documents defining the goals, objectives, requirements, content of knowledge and skills, the overall structure of the subjects and plans [2]. Class planning and internships for each academic year, the ratio of subjects, between theory and practice, stipulating methods, methods, facilities, facilities, certificates and graduation certificates Department of Education and Training.A training program is a description of the overall components of a training process including the training objectives, the expected learning outcomes of the program, the content of training, and organization, conditions, process of training 
organization and evaluation of training results [3].

Regardless of the approach, the concepts of the program emphasize: i) a pedagogical action plan that connects the training objective with the content, method, form of training organization and manner result evaluation; ii) ensure the link between training objectives and learning outcomes and training organization process to achieve output standards.Developing a school program is a process in which some or all members of the school plan to implement and evaluate one or more aspects of the program that the school is using. This could be adjusting an existing program, accepting unchanged, or creating a new program. Developing a school program is a collective effort within the framework of an accredited framework that is not hindered by any personal efforts of teachers or other administrators [4].

In fact, the basic arguments for school program development: (i) Engage teachers' participation in decisions related to program development and implementation; (ii) May involve a part of the teacher, not the whole teacher; (iii) It may be a "selection and adjustment" program, not an entirely new one; (iv) It only includes changing the position of the school's responsibility in the decisions related to the program but not referring to the school's other relationship with the management; (v) This is a continuous and dynamic process that attracts teachers, students and the community to participate; (vi) Satisfy the needs of many support structures; (vii) Changing the traditional role of teachers [2].

According to the author of the training program development, it is the process of adjusting, supplementing, updating and refreshing all or some components of the training program, ensuring the relative development and stability of the training program. Already, in order to make the implementation of the program according to the training objectives set out to achieve the best effect, consistent with the characteristics and development needs of the society and individual learners' development. Program development includes program development, evaluation, modification and completion [5].

Program development is a process of continuous improvement of the program at all different levels including the national program level, the school training program level, the subject program level; program level of each lesson, each teaching and learning activity.This is a relatively new concept to Vietnam because the concept of "rooting" in lecturers is that the program must be stable, long-lasting and packaged for all audiences. It is the thought that is a barrier affecting the program development capacity of teachers of pedagogical universities in Vietnam.

Lecturers 'capacity to develop training programs are supplementary, updated, adjusted, perfected and renewed lecturers' programs conducted on the basis of proper awareness about context, programs and organize effective implementation of training activities in relationships with stakeholders. Facing with the ever-changing requirements of general teachers' capacity, pedagogical university faculty members must master the competency requirements of new teachers and recruiter's orders, and build a standardof the program in order to respond to employer requirements and the job market; accurately identify standards of professional teachers in each period; design the program content according to the developed output standards; assess the results of program implementation and the program's fulfillment of teacher training activities [4].

Teachers' program development capacity includes some competencies including the ability to update and supplement new content in teaching subjects and lessons; ability to refresh the program and capacity to evaluate training programs:

(1) Ability to update and supplement new contents in teaching and training occupational skills for students;

(2) The capacity to refresh the training program includes the capacity to determine the objectives of the teacher 
training program and the ability to match the objectives with the output standards; the capacity to develop training program output standards, capacity of labor market survey, employers, alumni to identify career and graduate competency profiles, cooperation capacity with lecturers and other stakeholders to determine the outcome of the training program; the ability to select knowledge modules and subject groups to meet the program's objectives and output standards; the ability to compare the identified new subject with the current framework program, eliminate subjects that are not appropriate, supplement new subjects to meet the learning outcomes, develop a new framework program; the capacity to design subject outlines and organize teaching based on subject outlines, assess student learning outcomes; and the capacity to self-assess the training program and improve the program after the comments of the stakeholders [5].

(3) Capacity to evaluate training programs includescompetence to understand and apply standards, criteria, indicators and landmarks in the evaluation of specialized training programs; the ability to store evidence and establish evidence system; the capacity to write program self-assessment reports; the capacity to comment, review and assess selfassessment reports based on criteria.

\section{B.Current Situation of the Capacity of Curriculum Development of Lecturers in Vietnamese Pedagogical} Universities

\section{Survey Organization}

The purpose of the survey is to assess the current situation of the capacity of developing training programs for teachers of Vietnamese pedagogical universities on the basis of which the content of training capacity development is proposed. develop programs for teachers of pedagogical universities.

Survey subjects include 225 management staff and pedagogical teachers of 5 pedagogical universities and pedagogical faculties with teacher trainingsuch as Thai Nguyen University of Education; Hue Pedagogical University; Vinh University; Dong Thap University; Hanoi Pedagogical University 2. Survey subjects represent regional characteristics, particular characteristics of pedagogical training environment and pedagogical training environment in multi-disciplinary schools.

\section{Content of the Survey}

Survey methods were designedwith questionnaires and in-depth interviews, product research on programs of some specialties.Survey results are processed on PSS software. The level of assessment in the criteria is assessed according to 4 levels in which the highest level is 4 points. The average score for each criterion: The average score from 1.0 to 1.75 is weak and unnecessary; From 1.75 to 2.5 reach the average level, relatively necessary; from 2.5 to 3.25 reach a good level, necessary; from 3.25 to 4.0 to reach an excellent level, very necessary.

\section{Survey Results}

Table 1: Current status of capacity development of training programs for lecturers in Vietnamese pedagogical universities

\begin{tabular}{|c|c|c|c|c|c|c|c|c|c|}
\hline \multirow{3}{*}{$\begin{array}{l}\text { Capacity to develop } \\
\text { training programs }\end{array}$} & \multicolumn{8}{|c|}{ Achieved levels } & \multirow{3}{*}{ Total } \\
\hline & \multicolumn{2}{|c|}{ Excellent } & \multicolumn{2}{|c|}{ Good } & \multicolumn{2}{|c|}{ Average } & \multicolumn{2}{|c|}{ Weak } & \\
\hline & SL & $\%$ & SL & $\%$ & SL & $\%$ & SL & $\%$ & \\
\hline $\begin{array}{l}\text { 1. Designing labor market } \\
\text { survey tools }\end{array}$ & 14 & 6.2 & 62 & 27.6 & 124 & 55.1 & 25 & 11.1 & 2.29 \\
\hline $\begin{array}{l}\text { 2. Surveying labor market } \\
\text { to develop training }\end{array}$ & 14 & 6.2 & 65 & 28.9 & 122 & 54.2 & 24 & 10.7 & 2.31 \\
\hline
\end{tabular}




\begin{tabular}{|l|c|c|c|c|c|c|c|c|c|}
\hline programs & & & & & & & & & \\
\hline $\begin{array}{l}\text { 3. Setting goals and } \\
\text { output standards of the } \\
\text { program }\end{array}$ & 24 & 10.7 & 127 & 56.4 & 63 & 28 & 11 & 4.9 & $\mathbf{2 . 7 3}$ \\
\hline $\begin{array}{l}\text { 4.Identifying knowledge } \\
\text { modules that meet the } \\
\text { output standards }\end{array}$ & 24 & 10.7 & 112 & 49.7 & 84 & 37.3 & 5 & 2.3 & $\mathbf{2 . 6 9}$ \\
\hline $\begin{array}{l}\text { 5. The subject } \\
\text { combination meets the } \\
\text { program learning } \\
\text { outcomes }\end{array}$ & 24 & 10.7 & 107 & 47.5 & 90 & 40 & 4 & 1.8 & $\mathbf{2 . 6 7}$ \\
\hline $\begin{array}{l}\text { 6. Matching new training } \\
\text { with the current program }\end{array}$ & 9 & 4 & 102 & 45.3 & 106 & 47.1 & 8 & 3.6 & $\mathbf{2 . 5 0}$ \\
\hline $\begin{array}{l}\text { 7. Discarding subjects } \\
\text { that do not meet the } \\
\text { output standards }\end{array}$ & 18 & 8 & 106 & 47.1 & 82 & 36.4 & 19 & 8.4 & $\mathbf{2 . 5 5}$ \\
\hline $\begin{array}{l}\text { 8. Supplement new subjects } \\
\text { to meet the learning } \\
\text { outcomes }\end{array}$ & 7 & 3.1 & 101 & 44.9 & 99 & 44.0 & 18 & 8.0 & $\mathbf{2 . 4 3}$ \\
\hline $\begin{array}{l}\text { 9. Developing subject } \\
\text { detailed outline }\end{array}$ & 26 & 11.6 & 127 & 56.4 & 63 & 28 & 9 & 4 & $\mathbf{2 . 7 6}$ \\
\hline $\begin{array}{l}\text { 10.Updating the content } \\
\text { of new teaching } \\
\text { knowledge in the subject } \\
\text { outline }\end{array}$ & 26 & 11.6 & 103 & 45.7 & 89 & 39.6 & 7 & 3.1 & $\mathbf{2 . 6 6}$ \\
\hline $\begin{array}{l}\text { 11.Organizing teaching } \\
\text { that meet the subject's } \\
\text { learning standards }\end{array}$ & 22 & 9.8 & 133 & 59.1 & 62 & 27.5 & 8 & 3.6 & $\mathbf{2 . 7 5}$ \\
\hline $\begin{array}{l}\text { 12. Assessing student's } \\
\text { academic ability }\end{array}$ & 22 & 9.8 & 125 & 55.5 & 66 & 29.3 & 12 & 5.3 & $\mathbf{2 . 7 0}$ \\
\hline 13. Program evaluation & 17 & 7.6 & 72 & 32 & 100 & 44.4 & 36 & 16 & $\mathbf{2 . 3 1}$ \\
\hline $\begin{array}{l}\text { 14. Completing the } \\
\text { program after evaluation }\end{array}$ & 11 & 4.9 & 72 & 32 & 80 & 35.6 & 62 & 27.5 & $\mathbf{2 . 1 4}$ \\
\hline
\end{tabular}

The statistical results in the table show that the training program development capacity of teachers of pedagogical universities is not high, no capacity has reached an excellent level.

Competencies with a fairly good level include the ability to eliminate subjects that do not meet the output standard with an average of 2.55 . This is a very important ability to help the school and teachers teach what learners need without teaching what the school has. However, when exchanging with lecturer $\mathrm{H}$ at Thai Nguyen University of Education and lecturer $\mathrm{M}$ at Dong Thap University, this is an extremely difficult step for lecturers due to the influence of the old way and the private way. Only the module assigned to each teacher, if the module is lost, the teacher will lose teaching time.

The ability to update the content of new teaching knowledge in the course outline has an average of 2.66. This is also a limitation in the program development capacity of teachers of pedagogical universities at present, many lecturers believe that the program change is of the school, lecturers have no duty to supplement or update program content It is the above thinking that makes the way of teaching, how to organize lessons, and the lesson content lacking updated and modern [6].

The subject combination ability that meets the program's standard output scores an average of 2.67 and the ability to identify the knowledge module meeting the exit standard has an average of 2.69. This is the capacity to help teaching meet the program's output standards and meet the social needs, but the evaluation results of the lecturers are not high. The 
subject matrix is commensurate with the learning outcomes or some of the available, but compulsory, programs that do not represent a scientific way of developing training programs.

The student's academic competence is averaged at 2.70. A practical study of the evaluation tool of pedagogical university -Thai Nguyen University shows that the current practice of faculty evaluation is limited in such stages as determining the capacity matrix to be assessed according to the output standards; assessment tool design capacity; capacity to choose the form, method of evaluation and capacity to use assessment results to improve and develop the training program, question bank of the test, test has not really approached capacity.

The program's construction output standard capacity reaches an average score of 2.73. Analysis of the university's output standards and training programs shows that the output standard statements are general, difficult to measure the achieved results, the writing techniques and the statement of the university's standard output are not really convince [7].

The ability to develop detailed course outline has an average of 2.76 . This is the necessary and often required competence of the instructor. However, when studying some subject outline of lecturers, we found that the outline has not yet determined the capacity matrix of the subject output standards, or has been determined, it includes too many difficult standards to measure; the outline has not yet clearly shown the forms of teaching organization to meet the learning outcomes, has no effect on the orientation for self-learning activities, self-assessment of students' learning results [8].

The teaching capacity of the subject that meets the learning outcomes of the subject reaches an average of 2.75. This is a basic and important competency of lecturers, however, it is only at the level of good assessment, when attending the lectures and talking with lecturers, the lecturers have not really mastered the teaching method under the credit system, the old way of teaching is still popular, there are lecturers who try to innovate the teaching method but much more in the way of high school, project-based learning, seminar-based learning. Topics have not been used by teachers much to develop students' selfstudy and research capacity while this is the main form of teaching organization in universities [9].

Competences that have not been rated and are limited and only average are the following competencies of lecturers: Capacity of designing labor market survey tools and stakeholders; Although this is the capacity to play an important role in the development of the trainers' curriculum, giving teachers the tools to gather the necessary information from the labor market in order to understand the required capacity requirements. of graduates [7].

Ability to closely monitor the labor market to develop the training program; This is the ability to help teachers understand the requirements of recruiting teachers about the student's required personality and the feedback from employers and alumni about the shortcomings of the training program for lecturers. curriculum can be adjusted to meet practical needs [10].

The ability to add new subjects to meet the learning outcomes is the limited capacity, which leads to changes in the teaching content that meets barriers in curriculum development.Competency in evaluating training programs and curriculum; This is the ability to help teachers understand the advantages and shortcomings of the training program in general and the subject curriculum in particular to plan improvement to improve the quality of the program.

\section{Ability to use Program Evaluation Results to Complete the Training and Program Completion}

Research on a number of subject syllabus products and training programs of schools shows that schools have been interested in developing training programs in recent years, but the level is not deep, not following the process of reviewing, updating and 
developing the program, the addition to the training program of new content has not been conducted methodically. Course syllabus of some schools has not clearly shown the updated content and regular knowledge every year [8].

Talking with some lecturers of the schools showed that the development of new training programs has been interested in schools in the last 3 years after a training course of the Ministry of Education and Training, of which the University of Education and Training - Thai Nguyen University is core units implementing training courses, lecturers have not been much involved in program development activities, there are no legal provisions for lecturers in implementing teacher training program development. Training program development activities are usually carried out by a group of experts, mainly heads of faculties, faculties and lecturers who are little-known about training program development [11].

\section{General Assessment}

Pedagogical teachers have the capacity to develop teacher training programs but the level is not high and is limited in some competencies, especially the capacity to design tools and survey the labor market. and the capacity to self-assess the curriculum and curriculum of the subject, this is also the reason for the limitations of teacher training programs at pedagogical universities today. The cause of this situation is due to many reasons including the following basic causes: management; due to faculty awareness of program development and a number of other causes [12].

In order to survey and assess the training needs of pedagogical trainers, the research team used the questionnaire to conduct the survey and obtained the results shown in Table 2 .

Table 2: Demand for fostering training program development capacity of Vietnamese pedagogical university teachers

\begin{tabular}{|c|c|c|c|c|c|c|c|c|c|}
\hline \multirow{3}{*}{$\begin{array}{l}\text { The expected content to } \\
\text { participate in training on } \\
\text { program development }\end{array}$} & \multicolumn{8}{|c|}{ Levels } & \multirow{3}{*}{$\mathbf{T B}$} \\
\hline & \multicolumn{2}{|c|}{$\begin{array}{c}\text { Very } \\
\text { necessary (4) }\end{array}$} & \multicolumn{2}{|c|}{$\begin{array}{l}\text { Necessary } \\
\text { (3) }\end{array}$} & \multicolumn{2}{|c|}{$\begin{array}{c}\text { Rather } \\
\text { necessary } \\
(2)\end{array}$} & \multicolumn{2}{|c|}{$\begin{array}{c}\text { Unnecessary } \\
\text { (1) }\end{array}$} & \\
\hline & SL & $\%$ & SL & $\%$ & SL & $\%$ & SL & $\%$ & \\
\hline $\begin{array}{l}\text { 1. Defining a new framework } \\
\text { of teacher competencies }\end{array}$ & 125 & 55.6 & 70 & 31.1 & 19 & 8.4 & 11 & 4.9 & 3.37 \\
\hline $\begin{array}{l}\text { 2. Surveying the labor market } \\
\text { on the required competencies } \\
\text { of graduates }\end{array}$ & 100 & 44.4 & 100 & 44.4 & 20 & 8.9 & 5 & 2.2 & 3.31 \\
\hline $\begin{array}{l}\text { 3. Methods and techniques for } \\
\text { developing the program's } \\
\text { learning outcomes and subjects' } \\
\text { output standards }\end{array}$ & 113 & 50.2 & 87 & 38.7 & 10 & 4.4 & 15 & 6.6 & 3.32 \\
\hline $\begin{array}{l}\text { 4. The technique of defining } \\
\text { knowledge module meets the } \\
\text { output standard }\end{array}$ & 71 & 31.6 & 122 & 54.2 & 7 & 3.1 & 25 & 11.1 & 3.06 \\
\hline $\begin{array}{l}\text { 5. Technical reference } \\
\text { program of advanced } \\
\text { countries in the world and } \\
\text { the region }\end{array}$ & 105 & 46.7 & 75 & 33.3 & 35 & 15.6 & 10 & 4.4 & 3.22 \\
\hline $\begin{array}{l}\text { 6. The ability to compare new } \\
\text { subjects with the current } \\
\text { training program }\end{array}$ & 3 & 1.3 & 63 & 28 & 88 & 39.1 & 71 & 31.5 & 1.99 \\
\hline $\begin{array}{l}\text { 7. Technology to eliminate } \\
\text { subjects that do not meet the } \\
\text { output standards }\end{array}$ & 52 & 23.1 & 65 & 28.9 & 73 & 32.4 & 35 & 15.6 & 2.60 \\
\hline $\begin{array}{l}\text { 8. New subject addition } \\
\text { techniques meet the learning } \\
\text { outcomes }\end{array}$ & 41 & 18.2 & 85 & 37.8 & 20 & 8.9 & 79 & 35.1 & 2.39 \\
\hline
\end{tabular}




\begin{tabular}{|l|c|c|c|c|c|c|c|c|c|}
\hline $\begin{array}{l}\text { 9. Techniques to build detail } \\
\text { subject outline }\end{array}$ & 20 & 8.9 & 45 & 20 & 95 & 42.2 & 65 & 28.9 & $\mathbf{2 . 0 9}$ \\
\hline $\begin{array}{l}\text { 10. Method of choosing to } \\
\text { update the content of new } \\
\text { teaching knowledge in the } \\
\text { course outline }\end{array}$ & 53 & 23.6 & 79 & 35.1 & 7 & 3.1 & 86 & 38.2 & $\mathbf{2 . 4 4}$ \\
\hline $\begin{array}{l}\text { 11. Teaching methods, } \\
\text { measures and techniques to } \\
\text { meet the subject's learning } \\
\text { standards }\end{array}$ & 115 & 51.1 & 65 & 28.9 & 21 & 9.3 & 24 & 10.7 & $\mathbf{3 . 2 0}$ \\
\hline $\begin{array}{l}\text { 12. Methods and techniques for } \\
\text { assessing student learning } \\
\text { capacity }\end{array}$ & 101 & 44.9 & 67 & 29.8 & 42 & 18.7 & 15 & 6.7 & $\mathbf{3 . 1 3}$ \\
\hline $\begin{array}{l}\text { 13. Knowledge, program } \\
\text { evaluation skills }\end{array}$ & 125 & 55.5 & 55 & 24.4 & 40 & 17.7 & 5 & 2.2 & $\mathbf{3 . 3 3}$ \\
\hline $\begin{array}{l}\text { 14. Technical completion } \\
\text { program after evaluation }\end{array}$ & 112 & 49.8 & 77 & 34.2 & 23 & 10.2 & 13 & 5.8 & $\mathbf{3 . 2 8}$ \\
\hline
\end{tabular}

The above survey results show that lecturers of pedagogical universities in Vietnam have high demand for some content in developing teacher training programs. That means that determining the framework of capacity of general teachers (3.37 points) ranked 1); program knowledge and skills (3.33 points, ranked at the second position); methods and techniques for developing the program's learning outcomes and the subject's learning standards (3.32 points at the third rank); surveying the labor market on the required capacity of graduates (3.31 points ranked fourth); technical completion program after evaluation (3.28 points ranked 5th); technical reference programs of advanced countries in the world and the region (3.22 points ranked sixth priority); teaching methods, measures and techniques to meet the subject's learning standards (3.20 points in priority order No. 7); methods and techniques for assessing students' learning ability (3.13 points in priority order No. 8); the technique of defining knowledge module meets the output standard (the average is 3.06 ranked in the 9th order).

The remaining contents lecturers have a need for training at a lower level, but still at an average level means that there are still a large number of lecturers who need to foster those contents. Specifically, the following contents include the ways to choose to update the content of new teaching knowledge in the subject outline; technology to eliminate subjects that do not meet the output standards; new subject technology additions to meet learning outcomes; technical construction subject outline outlines; the ability to compare new subjects with the current training program [13].

General assessment of pedagogical teachers who need to foster capacity building program development is relatively high in many content presented at a very necessary level, especially the need to foster assessment competence curriculum and competence of teachers according to new teacher career standards; capacity building standards and reference training programs of advanced countries in the world etc. This is the point that training managers, lecturers management at pedagogical universities should be concerned.

\section{CONCLUSIONS}

The program development capacity of Vietnamese pedagogical university teachers has achieved certain results but has not been high. There are a limited number of capacities such as access to stakeholders and the labor market; capacity to add new modules to meet the standards; program self-assessment capacity; ability to use assessment results to adjust and perfect the training program. Teachers of pedagogical universities have relatively high demand for training content for teacher training program development. Principals of Vietnamese pedagogical universities and lecturers should take the 
initiative in fostering and fostering their own capacity in developing training programs to improve the quality of teacher training to meet the requirements of renewing the general education curriculum of Vietnam in the current context.

\section{Conflict of Interest}

No conflict of interest is noted in the paper

\section{AUTHOR CONTRIBUTIONS}

Professor Nguyen ThiTinh and Ha Thi Kim Linh contributed the ideas, then Huynh Tan Hoi translated and checked the paper. All of us read related books, materials and then designed the paper together. At last, we had approved the final version.

\section{REFERENCES}

1. Altbach, P. G., \& Knight, J. (2007). The internationalization of higher education: Motivations and realities. Journal of studies in international education, 11(3-4), 290-305.

2. Dang, T. T. (2010). Learner Autonomy in EFL Studies in Vietnam: A Discussion from Sociocultural Perspective. English Language Teaching, 3(2), 3-9.

3. Moses, Chinonye, et al. "Entrepreneurship education and action-oriented pedagogical approaches." International Journal of Educational Science and Research 5.5 (2015): 53-60.

4. Do, T. T. (2019). Pedagogical and Professional Perspectives on Developing Graduate's Employability-The Case of University Translation Programs in Vietnam. Transformation and Empowerment through Education: Reconstructing Our Relationship with Education, 95-115.

5. Bui, T. T., Duong, G. T. H., Kieu, M. H., Pham, T. L., Nguyen, T. A. M., Luu, T. D.,..\& Nguyen, V. C. (2020). Application of Project-based Learning for Primary Teachers-A New Direction in Professional Training at Pedagogical Universities and Colleges in Vietnam.

6. JAIMINI, NIRUPMA. "SCIENCE MUSEUMS AS PEDAGOGICAL RESOURCE: TASK BASED FACILITATION."International Journal of Humanities and Social Sciences (IJHSS) 5. 6, Oct - Nov 2016; 15-22

7. Fedorov, V. A., \&Tretyakova, N. V. (2016). The Development of Vocational Pedagogical Education in Russia (Organizational and Pedagogical Aspect). International Journal of Environmental and Science Education, 11(17), 9803-9818.

8. Ezati, B. A., Opolot-Okurut, C., \&Ssentamu, P. N. (2014). Addressing Pedagogical Training Needs of Teaching Staff: Lessons from Makerere University Short Professional Development Programs 2006-2010. American Journal og Educational Research, 2(12), 1190-1198.

9. Ageli, Nuri R. "HUMOUR AS USED AND PERCEIVED BY INSTRUCTORS IN EFL TEACHING AT THE UNIVERSITY OF BAHRAIN. "International Journal of Humanities and Social Sciences (IJHSS) 7. 2, Feb - Mar 2018; 9-20

10. Chen, N. S., Wang, Y., Wu, P. J., \& Levy, M. (2008, July). Developing a pedagogically meaningful e-tutor training program for cyber face-to-face language teaching. In 2008 Eighth IEEE International Conference on Advanced Learning Technologies (pp. 361-365). IEEE.

11. Mishra, Sudha. "Heterogeneous Groups in Competition: Innovative Pedagogy for Teaching English as Second Language." International Journal of Educational Science and Research 4.3 (2014): 1-6.

12. Zhigalev, B. A., Vikulina, V. A., \&Bezukladnikov, K. E. (2014). Pedagogical measuring of education quality. Life Science 
Journal, 11(7s), 356-359.

13. Colbert, J. A., Brown, R. S., Choi, S., \& Thomas, S. (2008). An investigation of the impacts of teacher-driven professional development on pedagogy and student learning. Teacher Education Quarterly, 35(2), 135-154.

14. Thang, N. N., \&Quang, T. (2007). International briefing 18: training and development in Vietnam. International journal of training and development, 11(2), 139-149.

15. Vu, T. L. A., \& Le, T. Q. (2019). Development orientation for higher education training programme of mechanical engineering in industrial revolution 4. 0: a perspective in vietnam. J. Mech. Eng. Res. Dev, 42(1), 68-70.

16. Nguyen, T. L. H. (2012). Identifying the training needs of heads of department in a newly established university in Vietnam. Journal of Higher Education Policy and Management, 34(3), 309-321.

17. Pham, H. A., \& Ta, B. T. (2016). Developing a theoretical framework for ESP teacher training in Vietnam. The Asian ESP Journal, 12(1), 66-84. 

